\title{
SIMULATION OF INITIATION AND DEVELOPMENT OF CORROSION CRACKS IN ZIRCONIUM FUEL CLADDINGS UNDER CONDITIONS OF STRESS CORROSION CRACKING IN ENVIRONMENT OF IODINE
}
A.S. Sotnikov
en7@power.bmstu.ru

Bauman Moscow State Technical University, Moscow, Russian Federation

\begin{abstract}
The process models of iodine corrosion cracking of zirconium fuel claddings, used to calculate the durability of the cladding (time for loss of tightness) are considered. A method for determining the corrosion crack propagation rate in claddings made of E110 alloy $\varnothing 9.1 \times 0.65 \mathrm{~mm}$ and the results of corresponding studies (estimation of corrosion crack propagation rate and stress intensity factor $K_{\text {ISCC }}$ ) are given at a temperature of $380{ }^{\circ} \mathrm{C}$ in iodine environment at a concentration of $\sim 0.2 \mathrm{mg} / \mathrm{cm}^{2}$. Studies were performed using tubular samples with a fatigue crack. A fatigue crack on the inner surface of cladding made of E110 Ø $9.1 \times 0.65 \mathrm{~mm}$ alloy is the initiator of a corrosion crack emergence (nucleation). The results of corresponding studies are consistent with data from the literature. The proposed study of the corrosion cracking process of fuel claddings in accordance with the results of fracture mechanics is of practical importance for substantiation of the regulation of reactor operating conditions
\end{abstract}

\section{Keywords}

E110 zirconium alloy, fuel cladding, stress corrosion cracking, simulation, reactor, operation

Received 13.06.2018

(C) Author(s), 2019

Introduction. The experience of operating nuclear power plants (NPP) with thermal neutron reactors made it possible, based on fuel elements failure cause analysis, to determine that the interaction between the fuel and the cladding during non-stationary (transient) operating conditions may lead to burst of the fuel claddings. The most probable mechanism for such burst is cracking of zirconium claddings due to stress corrosion (SCC) at iodine exposure [1], which is released from the fuel during uranium fission. The release of atomic iodine in a fuel element can occur both as a result of chemical reactions involving oxygen and uranium fission products, and as a result of cesium iodide radiolysis [2], that determines the actual possibility of iodine corrosion of the claddings made from zirconium alloys in the presence of tensile stresses in them. 
Studies of the stress corrosion process of zirconium fuel claddings have been conducted since the mid-1960s. These studies are important for ensuring the operability of fuel element claddings in non-stationary (transient) operating conditions of a reactor facility. B. Cox and J. Wood [3] were among the first to study stress cracking of zirconium claddings in the iodine environment. Their studies underlie the cracking mechanisms known today.

Cracks propagation under stress corrosion can occur in zirconium alloys by intragranular, intergranular and mixed mechanisms [4-6]. In the iodine environment at $T=300{ }^{\circ} \mathrm{C}$ stress corrosion propagates predominantly by an intragranular mechanism, although there is always at least a small fraction of intergranular fracture. Intergranular fracture usually propagates at the initial stage of the process. Such a transition corresponds to an increase in the stress intensity factor at the crack tip to values greater than the critical ones ( $\left.K_{\text {ISCC }}\right)$. At elevated temperatures, intergranular fracture in zirconium alloys during stress corrosion tests in iodine environment occurs by dissolving grain boundaries removal of volatile zirconium iodides from these boundaries. At that, the initial crack grows until the critical stress intensity factor $\left(K_{\mathrm{ISCC}}\right)$ is reached, at which the crack begins to propagate in an intragranular manner. Removal of volatile iodides from grain boundaries may be accompanied by the deposition and recovery of iodine particles at the tip or the beginning of the crack, which may be the reason for the formation and accumulation of various impurities and alloying elements in these places. If the initial stage of corrosion of a zirconium alloy under stress is intergranular fracture, then the rate of such grain boundary cracking is determined by the microstructure (grain size, size and distribution of the minor phase particles, segregations of alloying elements or impurities).

Intragrain destruction occurs by the quasi-spalling mechanism - due to the adsorption of iodine atoms or iodides, which diffuse into the crack tip and weaken interatomic bonds there in certain crystallographic planes. The crack propagates along the basal planes of the zirconium lattice.

It is necessary to add that the chemical composition of the alloys is the main factor influencing the stress corrosion process of zirconium claddings. At the same time, as the chemical composition changes, the structure and phase composition, mechanical and physical properties of the alloys simultaneously change. They affect the resistance of claddings to stress corrosion primarily through a change in their strength, and this effect manifests itself in the initial stages of fracture.

Texture has a significant influence on the initiation and on the propagation of cracks in zirconium alloys during stress corrosion of the claddings. At that, the effect of the texture is stronger than effect of the alloy's chemical composition. 
The results of most studies are consistent with the fact that an intragranular quasi-spalling crack propagates along the basal planes of the zirconium lattice. The effect of texture on resistance of zirconium claddings to stress corrosion can be traced mainly under conditions when the crack growth mechanism is intragranular.

Thus, studies of the stress corrosion process of fuel claddings in iodinecontaining environment have shown that the main mechanisms of the "iodine" process in zirconium alloys are adsorption in the case of intragranular fracture and chemical dissolution of grain boundaries in the case of intergranular fracture $[4,5]$.

It has been determined that stress corrosion cracking of zirconium fuel claddings occurs in three stages [1,4]: 1) initiation of cracks, 2) their quasistationary growth in a corrosive environment under stress, and 3) ductile failure (rupture) of the remaining cladding section. Most of the time before fracture takes the first two stages. In this paper, we consider the second stage, namely, the stage of quasi-stationary crack growth.

The existing theoretical models of quasi-stationary crack growth in the iodine environment mainly come to building a correlation dependence of their growth rate on the stress intensity factor based on one or another set of experimental data. The use of such models is limited due to the large scatter of data obtained from different authors.

Work objective - to analyze some features of the stress corrosion models for zirconium fuel claddings, including some features of research in the power excursion mode [6], providing a study of simulative fuel assemblies in the mode of fast power surges (excursions), imitating load following (transient) processes and allowing to control a nuclear reactor using neutronics and fuel codes, as well as the results of experimental studies of quasi-stationary growth of corrosion crack in the fuel claddings $\varnothing 9.1 \times 0.65 \mathrm{~mm}$ from E110 alloy at iodine concentrations of $\sim 0.2 \mathrm{mg} / \mathrm{cm}^{2}$ and temperature of $380{ }^{\circ} \mathrm{C}$, depending on the level of applied tensile stress.

Comparative analysis of stress corrosion models for zirconium fuel claddings. The task of preserving the leak tightness of the fuel claddings when maneuvering the power of NPP also remains relevant today. Therefore, it seems important to regulate the operating conditions of fuel elements by acceptable level and change rate of power, taking into account the fuel burn-out [2]. Many studies have been devoted to the nature and conditions of the emergence of the SCC process, the results of which are to some extent summarized in [4-6].

In accordance with the requirements of foreign and Russian supervisory authorities [7, 8], when developing an engineering design of a fuel element, all 
mechanisms for the possible destruction of it, including the mechanism of stress corrosion, should be taken into account.

The stress corrosion process proceeds in time at different rates depending on external loading parameters (stress, temperature, iodine concentration) and characteristic properties of the cladding material structural condition, which is mainly determined by their manufacturing technology and degree of radiation damage. This determines the possibility of using fracture mechanics to predict the fuel claddings strength with a depth of the original fatigue crack, which should not exceed the thickness of the latter, i.e., $0.65-0.9 \mathrm{~mm}$.

To calculate the durability of the claddings (time for loss of tightness), models are used that can be divided into two groups [9].

In the models of the first group, the cladding wall is conventionally divided into a series of sequentially destructing elements of a predetermined thickness upon reaching the required stress level and critical concentration of iodine, which can be interdependent. The calculation formulas for this model are partly empirical in nature and change during the transition from intergranular to intragranular fracture [9-11].

Models of the second group use a relatively traditional approach of fracture mechanics, which relates the design survivability to the crack propagation kinetics, that is, to the dependence of its extension rate on the parameter characterizing the stress state at the top. Assuming that stress corrosion damage occurs by cleavage, the stress intensity factor $\left(K_{\mathrm{ISCC}}\right)$ is taken as such a parameter $[12,14,15]$.

Note that in the models of the first group, this dependence is also indirectly used with the exponent of the equation relating $K_{\text {ISCC }}$ to the crack growth rate as a fracture behavior criterion in one or another analytical calculation technique.

Therefore, the aforementioned regulation of reactor operating conditions should be based on experimental data on the kinetics of the stress corrosion process.

Probably, one of the approaches to the modeling of cracking (crack propagation) may be the dependence of creep deformation in the state of plane deformation zone in front of a propagating crack, depending on the iodine concentration.

The crack starting time is determined by the crack opening at its top, and the crack growth rate after its starting $(\delta)$ is determined by the material parameters defining the deformation, by the height $(h)$ of the fracture process zone (commensurate with the grain size of the zirconium alloy) and by stress intensity factor $\left(K_{\mathrm{ISCC}}\right)$.

One distinctive feature of the crack propagation process is the ability to estimate its propagation by changing the size. The first stage of crack growth can 
be also considered the final stage of its formation. At the stage of initiation, a crack is formed as a result of microcracks coalescence under the shear stresses action. The process of microcracks formation differs from the process of their further propagation, since at the first stage these are shear cracks, which then propagate as opening mode cracks.

The phenomenon of sensitivity to strain rate is of great importance, since it is postulated that at some reactor power growth rates, an increased tendency of fuel elements to fracture during fuel-cladding interaction (FCI) may appear and, as a consequence, a corrosion process is possible.

On the curves of the relative strain-to-fracture vs the strain rate a minimum is found, which manifests itself as the concentration of iodine increases from $10^{-3}$ to $10^{-2} \mathrm{mg} / \mathrm{cm}^{2}$. Such data for fuel claddings of E110 alloy were obtained in [15].

Apparently, the time to crack starting and the time to fracture are rather a consequence than causes of stress corrosion cracking and, probably, they can be used as independent variables in modeling.

It should be noted that the process of fuel claddings destruction during stress corrosion is controlled by diffusion, and the cladding behavior controlled by diffusion is possible for some fast transients during fuel elements irradiation.

Limiting the cracks propagation by the diffusion process can play an important role for already existing deep cracks (incipient cracks) during relatively fast transient conditions, like reactor power surge. Apparently, at high stresses, the fracture process mainly occurs by creep rupture, whereas at low stresses (long-term laboratory tests), relaxation during creep reduces stresses to values below the threshold.

High stresses for the time dependence of stress corrosion and limiting the iodine concentration [2] lead to destruction under stress corrosion conditions, which originates as intergranular and spreads as transgranular.

\section{Analysis of studies of zirconium fuel claddings in relation to the power} surge. The problem of iodine corrosion cracking of zirconium claddings is extremely important for ensuring the operability of spent fuel elements in transient (load following) conditions. Therefore, special experiments and postreactor studies of simulative fuel assemblies and individual full-scale fuel rods with fresh and spent fuel in the mode of fast power surges (excursions), simulating transients, have been developed.

Such tests with short pulses are performed in pulsed reactors: IGR (Kazakhstan), BIGR (RFNC - VNIIEF) and in the irradiation device of the MIR reactor (SSC RIAR), and with a pulse duration of more than a few tenths of a second - in the SM reactor (SSC RIAR). 
Possible changes of individual parameters (iodine concentration, temperature, stress) in the of power surge mode according to [6] are presented in Fig. 1 and Fig. 2.
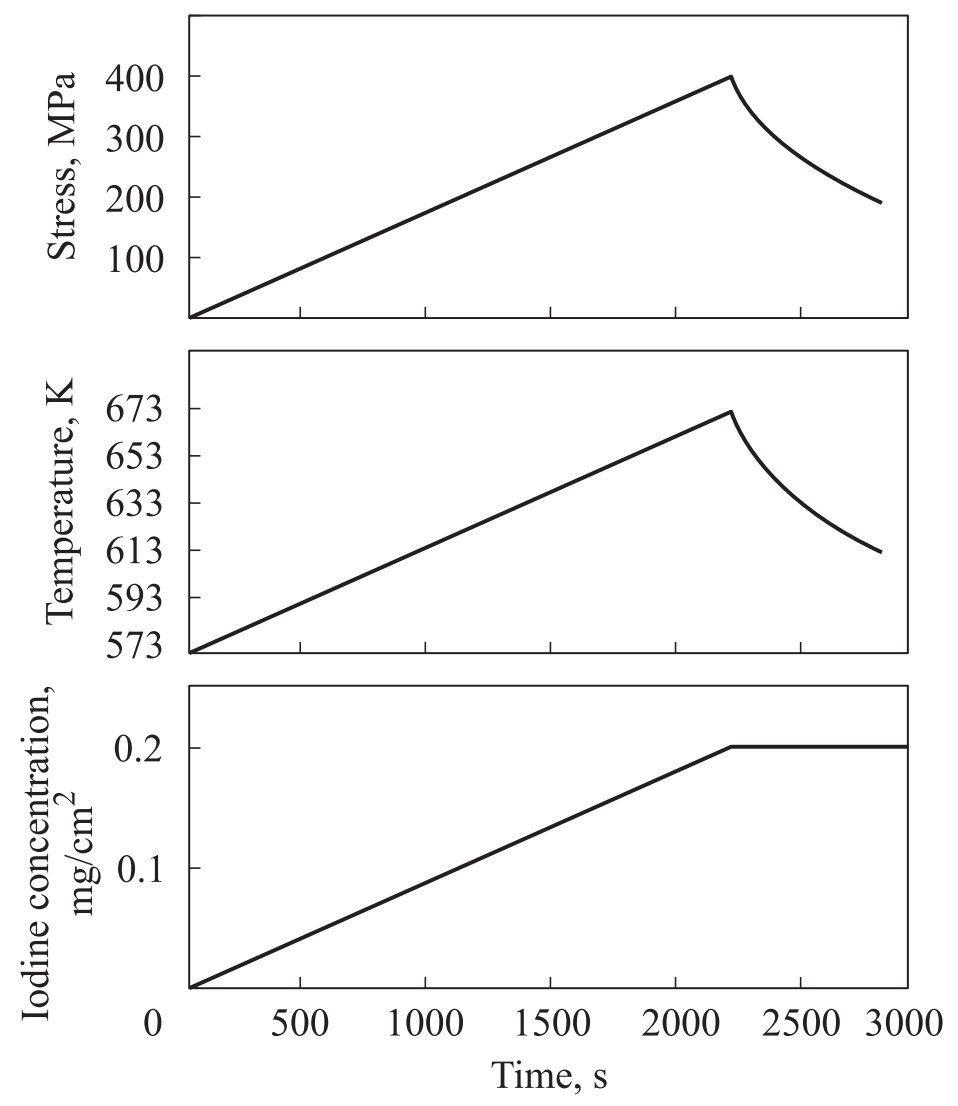

Fig. 1. Change of stress, temperature and iodine concentration in the power surge mode

The crack growth in the cladding in the power surge mode, presented in Fig. 1, for unirradiated zirconium $-4\left(\sigma_{0.2}=483 \mathrm{MPa}\right.$; $\left.\sigma_{\text {uts }}=552 \mathrm{MPa}\right)$ is shown in Fig. $2, a$, and for irradiated zirconium $-4\left(\sigma_{0.2}=620 \mathrm{MPa} ; \sigma_{\text {uts }}=690 \mathrm{MPa}\right)-$ in Fig. 2, $b$. The thickness of the zirconium cladding was $0.75 \mathrm{~mm}$.

From Fig. 2, $a$ it follows that the crack starting (beginning of growth) in unirradiated zirconium- 4 for the given experimental conditions was $0.2 \mathrm{~h}$, and the kinetics of its growth indicates its arrest and the absence of destruction, while for irradiated zirconium-4 (Fig. 2, b) under the indicated experimental conditions the cladding was destroyed at a time of $0.48 \mathrm{~h}$.

It seems that the starting process and the propagation of a corrosion crack in laboratory (unirradiated claddings) experiments and irradiated claddings are different, although the mechanism of initiation and propagation is similar (Fig. 2).

Thus, the process of destruction of fuel claddings under conditions of fuelcladding interaction and stress corrosion is the following: 
- plastic deformation (emergence of the first macroscopic crack);

- actual destruction, which is determined by the rate of a macroscopic crack propagation and the level of tensile stresses at the corrosion crack mouth.
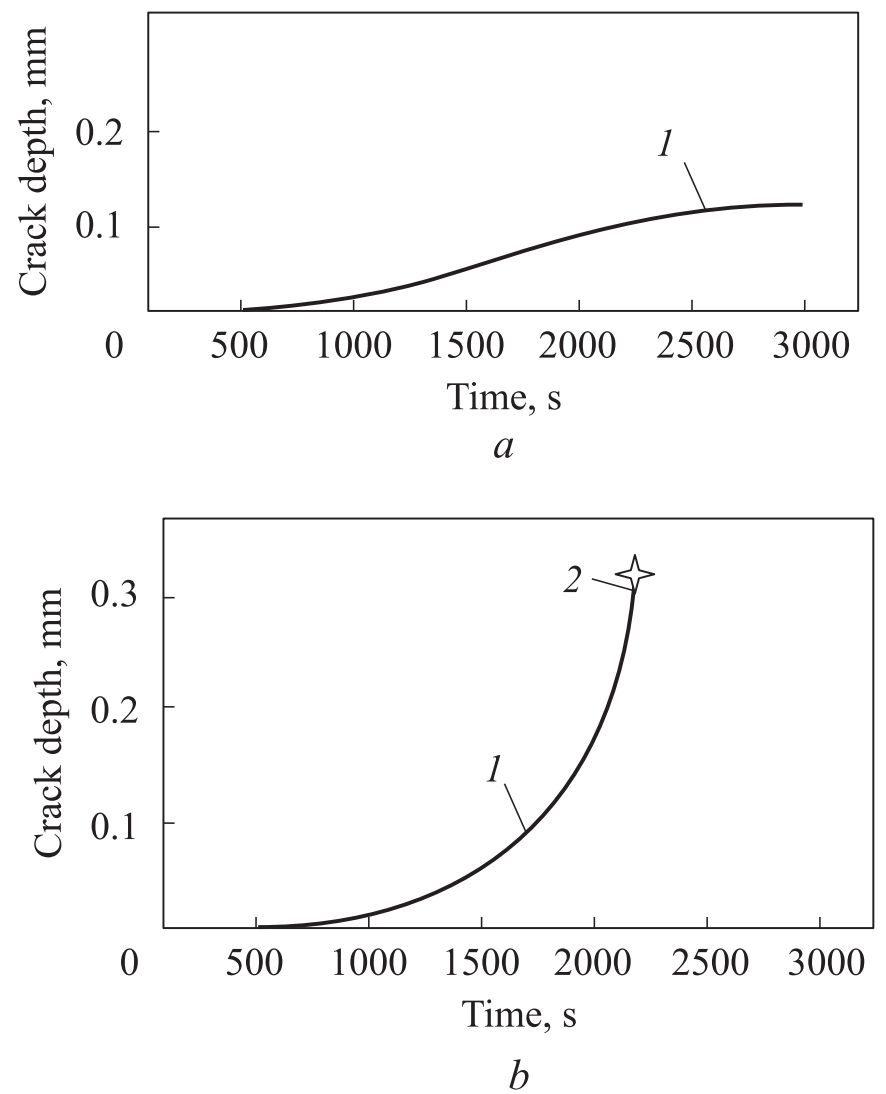

Fig. 2. The crack growth in the cladding of unirradiated $(a)$ and irradiated $(b)$ zirconium- 4 in the power surge mode:

$1(a)$ is stress relaxation in the cladding in the power surge mode, no destruction;

$1(b)$ is accelerated destruction (beginning) of the cladding; $2(b)$ is cladding destruction

Research methods and simulation results of the initiation and propagation of corrosion cracks under stress corrosion conditions. To experimentally justify the quasi-stationary growth of a corrosion crack (the second stage of propagation) in iodine environment under stress, it was assumed that for a brittle crack the maximum tensile stresses at its top are proportional to the stress intensity factor ( $\left.K_{\text {ISCC }}\right)$ [13].

As a result of long-term operation of the fuel element claddings under creep conditions, the destruction of the cladding material can occur at stresses less than the tensile strength in iodine environment.

The creep rupture strength properties of the cladding material, in general, are characterized by a set of stress rupture curves, which are plotted in the coordinates of the creep-rupture life - the applied stress. According to the results of creep-rupture tests at a constant iodine concentration on the basis of 
tests up to $\sim 1000 \mathrm{~h}$, the threshold stress values of the stress corrosion process at the corresponding test temperature are experimentally determined.

In real fuel elements, the amount of iodine is usually defined in grams or milligrams per $1 \mathrm{~kg}$ of $\mathrm{UO}_{2}$ fuel, depending on its burn-out and the gaseous fission product release $[2-6,15]$. The iodine concentration in tests with a constant initial amount of iodine in an experimental tubular sample is defined as a volume concentration $\left(\mathrm{mg} / \mathrm{cm}^{3}\right)$ or as a surface concentration $\left(\mathrm{mg} / \mathrm{cm}^{2}\right)$. At that, the required iodine concentration in an experimental tubular sample is determined by a specimen of iodine, which is loaded inside it before sealing and filling it with an inert gas (argon) to create the required level of tensile stresses in the cladding.

Calculations $[2,15]$ show that the release of stable iodine isotopes in the most stressed VVER-1000 fuel element at a burn-out of $\sim 50 \mathrm{MW}$.day/tU is $\sim 0.1-0.3 \mathrm{mg}$ of iodine $/ \mathrm{cm}^{2}$. When conducting laboratory experiments with a constant value of iodine concentration per unit of the inner surface of the cladding, an average value of $\sim 0.2 \mathrm{mg}$ of iodine $/ \mathrm{cm}^{2}$ was taken. At $T=380{ }^{\circ} \mathrm{C}$ and a surface concentration of iodine $\sim 0.2 \mathrm{mg} / \mathrm{cm}^{2}$, the threshold stress value of the stress corrosion process for unirradiated claddings $\varnothing 9.1 \times 0.65 \mathrm{~mm}$ from E110 alloy is $180 \mathrm{MPa}[15]$.

In the general case, the results of creep-rupture tests at an appropriate temperature are approximated by an equation of the following form:

$$
\sigma=A \log t_{i}+B
$$

where $\sigma$ is the value of tensile stresses; $t_{i}$ is the test time; $A$ and $B$ is material constants.

Thus, the allowable test time $\left(t_{i}\right)$ for a given tensile stress in equation (1) is determined based on the stress rupture curve at the corresponding test temperature.

The behavior of the zirconium claddings (alloy E110) was investigated using experiments on tubular samples of $\varnothing 9.1 \times 0.65 \mathrm{~mm}$ under an internal pressure of an inert gas (argon) with a fatigue crack with depth of $\sim 100 \mu \mathrm{m}$, length of $\sim 6 \cdot 10^{3} \mu \mathrm{m}$, an opening angle of $30 \pm 5^{\circ}$ and a radius at the tip of $\sim(10 \ldots 20) \mu \mathrm{m}$ previously created on the inner surface of the cladding, and with iodine concentration of $\sim 0.2 \mathrm{mg} / \mathrm{cm}^{2}$. At that, the crack parameters were monitored using non-destructive methods: ultrasonic and eddy current using reference samples [15].

The calculation of circumferential stresses $(\sigma)$ in the claddings of tubular specimens was carried out according to the formula:

$$
\sigma=P_{\mathrm{T}} d_{\mathrm{AV}} /(2 h)
$$


where $P_{T}$ is inert gas (argon) pressure at test temperature of $380{ }^{\circ} \mathrm{C} ; d_{\mathrm{AV}}$ is average outer diameter of the cladding; $h$ is average thickness of the cladding.

In the experiments carried out, the time $t_{i}$ was not more than $0.5 t_{\text {allow }}$ at tensile stresses values of 150 and $170 \mathrm{MPa}$ and at test temperature of $380^{\circ} \mathrm{C}$.

It was assumed that at the stage of subcritical crack propagation under stress corrosion, the instantaneous crack growth rate $(V)$ is constant and its average value can be described by the following expression:

$$
V=L_{i} / t_{i}
$$

where $L_{i}$ is the current size of the corrosion crack extension (the average measured value of the crack size) at the selected value of tensile stress leve; $t_{i}$ is the experiment time; $t_{i}<t_{\text {allow. }}$.

The study of stress corrosion of claddings was accompanied by a thorough analysis of the conditions for the crack propagation and their geometrical parameters using metallographic examinations after its extension for a given period of time $t_{i}$.

The results of the experiments at $T=380{ }^{\circ} \mathrm{C}$ are presented in Fig. 3 and in the table. Fig. 3 shows the cross-sections of samples with a crack in the initial state $(a)$ and after testing at $\sigma=150 \mathrm{MPa}(b)$ and $\sigma=170 \mathrm{MPa}(c)$.

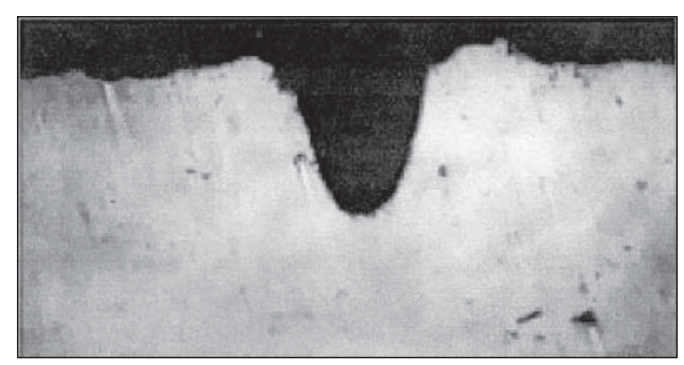

$a$

Fig. 3. The results of metallographic examinations of cladding samples from

E110 alloy with a previously created fatigue crack $(a)$ and after testing under stress corrosion conditions at $T=380{ }^{\circ} \mathrm{C}$ and stresses of $150 \mathrm{MPa}(b)$ and $170 \mathrm{MPa}(c)$, magnification $\times 150$

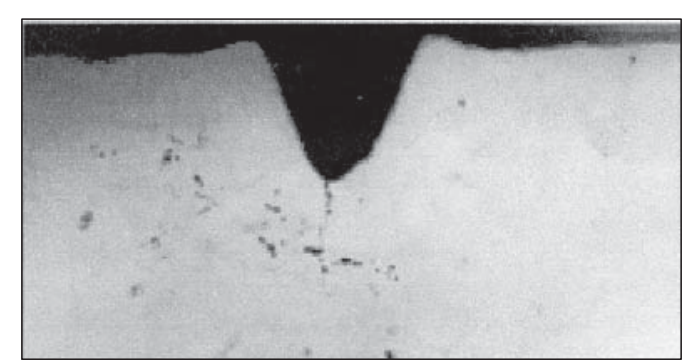

$b$

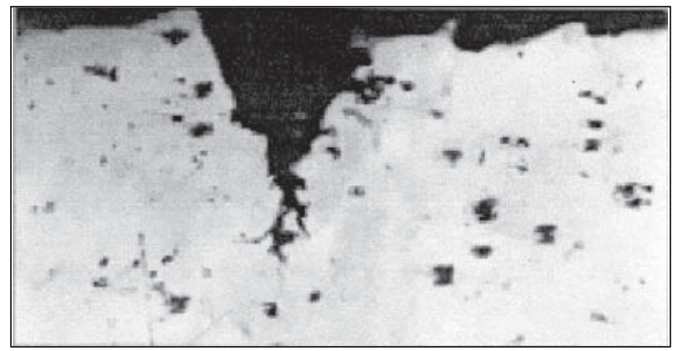

$c$

The summarized test results, including the calculated data of the current values of stress intensity factor and subcritical crack propagation rate are also shown in the table. The table presents some of the data from [13, 14] for comparison purposes. 
It follows from the above results that the crack propagation rate turned out to be more at higher stresses (comparison of $\sigma=150 \mathrm{MPa}(b)$ and $\sigma=170 \mathrm{MPa}(c)$ ).

Thus, an increase in stresses in the brittle area contributes to the acceleration of crack growth under given test conditions for stress corrosion.

The data from $[13,14]$ on tubular samples of the VVER type $\varnothing 9.1 \times 0.65$ $\mathrm{mm}$ [13] and of the RBMK type $13.6 \times 0.9 \mathrm{~mm}$ [14] presented for comparison are in satisfactory agreement with the data of this work.

It should be noted that the $K_{\text {ISCC }}$ value was calculated from the relation known from the literature [12-14]:

$$
K_{\text {ISCC }}=2,5 \sigma \sqrt{a_{c r}},
$$

where $a_{c r}$ is the crack depth; $\sigma$ is the circumferential stress.

\section{Summarized results of studies of claddings from E1 10 alloy under stress corrosion conditions (iodine concentration $\sim 0,2 \mathrm{mg} / \mathrm{cm}^{2}$ ) at $T=380{ }^{\circ} \mathrm{C}$}

\begin{tabular}{|c|c|c|c|c|c|}
\hline $\begin{array}{c}\text { Stress, } \\
\sigma, \mathrm{MPa}\end{array}$ & Test time $h$ & $\begin{array}{c}\text { Depth of crack } \\
\text { extension } \\
L_{i}, \mu \mathrm{m}\end{array}$ & $\begin{array}{c}\text { Stress intensity } \\
\text { factor } K_{\mathrm{ISCC}}\end{array}$ & $\begin{array}{c}\text { Crack } \\
\text { propagation } \\
\text { rate } L_{i} / t_{i}, \mathrm{~cm} / \mathrm{s}\end{array}$ & $\begin{array}{c}\text { Literature } \\
\text { sources }\end{array}$ \\
\hline 150 & 1.5 & 90 & 3.56 & $1.7 \cdot 10 \mathrm{~b}^{-6}$ & Present work \\
\hline 170 & 1.0 & 110 & 4.46 & $3.1 \cdot 10^{-6}$ & Present work \\
\hline 150 & - & 230 & 4.00 & - & {$[13]$} \\
\hline 146 & - & 329 & 4.92 & $1.53 \cdot 10^{-6}$ & {$[14]$} \\
\hline 97 & - & 420 & 4.56 & $2.21 \cdot 10^{-7}$ & {$[14]$} \\
\hline 110 & - & 325 & 4.49 & $1.75 \cdot 10^{-7}$ & {$[14]$} \\
\hline
\end{tabular}

It should be noted that carrying out works on stress corrosion of fuel claddings is necessary to further improve zirconium alloys and predict the behavior of fuel claddings in more severe operating conditions associated with an increase in the NPP energy resource due to an increase in burn-up range, an increase in the duration of the fuel cycle and the transition to load following reactor operation conditions [16].

Conclusion. Models of the corrosion cracking process of zirconium fuel claddings are discussed using relatively traditional approaches of fracture mechanics, linking the design survivability with the crack propagation kinetics.

The methodology and results of estimation of the corrosion crack extension rate and its propagation are presented depending on the level of applied tensile stresses in claddings $\varnothing 9.1 \times 0.65$ from E110 alloy at iodine concentration of $\sim 0.2 \mathrm{mg} / \mathrm{cm}^{2}$ and temperature of $380{ }^{\circ} \mathrm{C}$. 
The calculations of the corrosion crack growth (extension) rate and the $K_{\mathrm{ISCC}}$ values under these experimental conditions are consistent with known literature data determined on VVER and RBMK type zirconium fuel claddings.

Such studies of the initiation and propagation of corrosion cracks are of great importance for regulating the reactor operating conditions, especially in relation to the materials of fuel claddings of a new generation.

Translated by K. Zykova

\section{REFERENCES}

[1] Novikov V.V., Kuznetsov V.I., Nesterov B.I. [Reactor experimental validation of transition exploitation modes for VVER fuel elements]. Yadernoe toplivo novogo pokoleniya dlya AES [New-generation nuclear fuel for atomic power stations]. Moscow, AO "VNIINM", 2016.

[2] Sotnikov A.S., Novikov V.V., Medvedev A.V., et al. Effect of inner FR medium of high burnup fuel on shells destruction at corrosion cracking under stress conditions. Voprosy atomnoy nauki i tekhniki. Ser. Materialovedenie i novye materialy, 2012, no. 1, pp. 107-114 (in Russ.).

[3] Cox B., Wood J.S. Corrosion problems in energy conversion and generation. Electrochemical Society, 1974.

[4] Nikulin S.A. Corrosion cracking of $\mathrm{Zr}$ shell tubes (a review). I. Methods of the study and mechanisms of the fracture. Metallovedenie i termicheskaya obrabotka metallov, 2005, no. 2, pp. 31-39 (in Russ.).

[5] Nikulin S.A., Rozhnov A.B. Corrosion fracture of shell zirconium tubes. Review. 2. The effect of external factors, structure and properties of the alloys. Metallovedenie i termicheskaya obrabotka metallov, 2005, no. 9, pp. 30-37 (in Russ.).

[6] Sidky P.S. Iodine stress corrosion cracking of Zircaloy reactor cladding: iodine chemistry (a review). J. Nucl. Mater., 1998, vol. 256, no. 1, pp. 1-17.

DOI: $10.1016 /$ S0022-3115(98)00044-0

[7] PNAE G-1-024-90. (PBYa RU AS-89). Pravila yadernoy bezopasnosti reaktornykh ustanovok atomnykh stantsiy [PNAE G-1-024-90. (PBYa RU AS-89). Nuclear safety rules of reactor plants]. Moscow, Gospromatomnadzor SSSR Publ., 1990.

[8] NuREG-800. U.S. Nuclear regulatory commission, 2007.

[9] Miller A.K., Ocken H., Tasooji A. Iodine stress corrosion cracking of Zircaloy: laboratory data, phenomenological model and predictions of in-reactor behavior. J. Nucl. Mater., 1981, vol. 99, no. 2-3, pp. 254-268. DOI: 10.1016/0022-3115(81)90194-X

[10] Miller A.K., Shallenger K.D., Tasooji A. SCCIG: A phenomenological model for iodine stress corrosion cracking of Zircaloy. EPRI Report NR-1798. Vol. 1. Electric Power Research Institute, 1981.

[11] Tasooji A., Einizieger R., Miller A.K. Modeling of Zircaloy stress corrosion cracking: texture effects and dry storage spent fuel behavior. Zirconium in the nuclear industry. Proc. 6th Inter. Symp. ASTM STP 824, 1984, pp. 595-626. 
[12] Videm K., Lunde L., Hollowell T., et. al. Cracking of cladding tubes by power ramping and by laboratory stress corrosion experimental. J. Nucl. Mater., 1979, vol. 87, no. 2-3, pp. 259-267. DOI: 10.1016/0022-3115(79)90562-2

[13] Novikov V.V. Assessment of rupture resistance at corrosion of fuel element shell material fuel element under tension. Zavodskaya laboratoriya, 1984, vol. 85, no. 3, pp. 67-70 (in Russ.).

[14] Bibilashvily Yu.K., Dolgov Yu.N., Nesterov B.I., et al. Propagation of stress corrosion cracks in Zr-1\% Nb claddings. J. Nucl. Mater., 1995, vol. 224, pp. 307-310.

DOI: 10.1016/0022-3115(95)00114-X

[15] Sotnikov A.S. Vliyanie yoda i yodida tseziya na korrozionnoe rastreskivanie pod napryazheniem obolochek iz splava Zr-1 \% Nb tvelov vodookhlazhdaemykh reaktorov. Dis. kand. tekh. nauk [Effect of iodine and cesium iodide on corrosion cracking of fuel element shells from $\mathrm{Zr}-1 \% \mathrm{Nb}$-alloy for water-cooled reactors. Cand. techn. sc. dis.]. Moscow, VNIINM Publ., 1989.

[16] Novikov V.V. Razvitie konstruktsiy i materialov tvelov dlya VVER. Dokl. na nauch.tekh. conf. "AO "TVEL": Yadernoe toplivo novogo pokoleniya. Rezul'taty razrabotki, opyt ekspluatatsii i napravlenie razvitiya” [Reports at the Sc.-Tech. Conf. JSC “TVEL”: Nuclear fuel of new generation. Results of development, exploitation experience and growth options]. Moscow, 2014 (in Russ.).

Sotnikov A.S. - Cand. Sc. (Eng.), Assoc. Professor, Department of Nuclear Reactors and Power Plants, Bauman Moscow State Technical University (2-ya Baumanskaya ul. 5, str. 1, Moscow, 105005 Russian Federation).

\title{
Please cite this article as:
}

Sotnikov A.S. Simulation of initiation and development of corrosion cracks in zirconium fuel claddings under conditions of stress corrosion cracking in environment of iodine. Herald of the Bauman Moscow State Technical University, Series Mechanical Engineering, 2019, no. 5, pp. 135-146. DOI: 10.18698/0236-3941-2019-5-135-146

Издательство МГТУ им. Н.Э. Баумана

105005, Москва, 2-я Бауманская ул., д. 5, стр. 1

press@bmstu.ru

http://baumanpress.ru

\author{
Подписано в печать 25.09.2019 \\ Формат $70 \times 108 / 16$ \\ Усл.-печ. л. 12,8
}
Отпечатано в типографии МГТУ им. Н.Э. Баумана
105005, Москва, 2-я Бауманская ул., д. 5, стр. 1
baumanprint@gmail.com

